\title{
Contrasting migratory responses of two closely related seabirds to long-term climate change
}

\author{
W. James Grecian ${ }^{1, *}$, Graeme A. Taylor ${ }^{2}$, Graeme Loh $^{3}$, Rona A. R. McGill ${ }^{4}$, \\ Colin M. Miskelly ${ }^{5}$, Richard A. Phillips ${ }^{6}$, David R. Thompson ${ }^{7}$, Robert W. Furness ${ }^{1}$ \\ ${ }^{1}$ Institute of Biodiversity, Animal Health \& Comparative Medicine, College of Medical, Veterinary \& Life Sciences, \\ University of Glasgow, Glasgow G12 8QQ, UK \\ ${ }^{2}$ Department of Conservation, PO Box 10420, Wellington 6143, New Zealand \\ ${ }^{3}$ Department of Conservation, PO Box 5244, Dunedin 9058, New Zealand \\ ${ }^{4}$ NERC Life Sciences Mass Spectrometry Facility, Scottish Universities Environmental Research Centre, Rankine Avenue, \\ East Kilbride G75 0QF, UK \\ ${ }^{5}$ Museum of New Zealand Te Papa Tongarewa, PO Box 467, Wellington 6140, New Zealand \\ ${ }^{6}$ British Antarctic Survey, Natural Environment Research Council, High Cross, Madingley Road, Cambridge CB3 0ET, UK \\ ${ }^{7}$ National Institute of Water and Atmospheric Research Ltd, Kilbirnie, Wellington 6021, New Zealand
}

\begin{abstract}
Many marine predators migrate between breeding and non-breeding areas to target resources that are seasonal but spatio-temporally predictable, and so are vulnerable to climateinduced changes in prey phenology and abundance. In the Southern Ocean, small petrels are major consumers, but perturbations in the ecosystem through ocean warming are altering foodweb structure and have been linked to poleward shifts in the distribution of their cold-water zooplankton prey. In this study, we focused on 2 small congeneric petrels: the broad-billed prion Pachyptila vittata and the Antarctic prion P. desolata. Both are planktivorous, but the broad-billed prion specialises in feeding on large copepods. We investigated historical trends in non-breeding distribution by analysing feather stable isotope ratios from a time-series dating back to 1926, and examined contemporary non-breeding distributions of broad-billed prions tracked using miniaturised geolocation-immersion loggers. After controlling temporally for the Suess effect, we found that the $\delta^{13} \mathrm{C}$ signatures of Antarctic prions, but not broad-billed prions, declined during the study period. This suggests a southward shift in Antarctic prion non-breeding distribution over the last century. Both species exhibited significant declines in $\delta^{15} \mathrm{~N}$ during the same period, indicative of long-term decreases in marine productivity in their moulting areas, or changes in the trophic structure of prey communities. Tracked broad-billed prions migrated ca. $1000 \mathrm{~km}$ to an area east of the breeding colony where the Louisville seamount chain bisects the subtropical front. Topographically driven upwellings are stable and predictable features and may be crucial in aggregating plankton. Targeting seamounts could therefore mitigate the impact of climate-induced prey shifts by providing refugia for the broad-billed prion.
\end{abstract}

KEY WORDS: Biologging - Conservation · Migration · Moult · Movement · Non-breeding behaviour $\cdot$ Seamounts $\cdot$ Stable isotopes $\cdot$ Upwelling zones

\section{INTRODUCTION}

Rapid climate change has resulted in shifts in the distribution of a wide range of taxonomic groups (Parmesan \& Yohe 2003, Hickling et al. 2006, Chen et

${ }^{*}$ Corresponding author: james.grecian@glasgow.ac.uk al. 2011). There is mounting evidence to suggest that ecological responses to climate change are more pronounced in marine than terrestrial ecosystems (Boyce et al. 2010, Beaugrand et al. 2014), and changes are being observed from species to commu-

(C) The authors 2016. Open Access under Creative Commons by Attribution Licence. Use, distribution and reproduction are unrestricted. Authors and original publication must be credited. 
nity levels (Beaugrand et al. 2002, 2014, Edwards \& Richardson 2004). Species may respond to climate change by tracking habitat changes either in time, through phenological shifts in the timing of breeding or migration (Cotton 2003, Gill et al. 2014), or in space, through biogeographic shifts in latitude, altitude or water depth (Beaugrand et al. 2002, Perry et al. 2005, Quillfeldt et al. 2010). However, variation in the level of response or capacity to adapt to climate change within an ecological community (Chen et al. 2011) could lead to the decoupling of trophic linkages, altering food-web structure and potentially resulting in ecosystem-level changes (Loeb et al. 1997, Edwards \& Richardson 2004, Thuiller 2004).

Migratory marine predators such as seabirds undertake some of the longest known migrations (Shaffer et al. 2006, Egevang et al. 2010) and so are vulnerable to climate-induced changes in prey phenology, abundance and distribution. Small petrel species are major consumers of zooplankton (Guinet et al. 1996, Brooke 2004, Navarro et al. 2013) and associate with major frontal systems to target small copepods in the Southern Ocean (van Franeker et al. 2002). In the waters east of New Zealand, the position of the subtropical front is strongly influenced by interactions with the shallow topography of the New Zealand continental shelf and the Chatham Rise (Sutton 2001, Smith 2013). There is strong seasonality in zooplankton biomass in the subtropical front region; the spring vertical migration of the copepod Neocalanus tonsus can constitute up to $64 \%$ of the total dry weight in surface waters (Bradford-Grieve et al. 1999). Ocean warming has been linked to a poleward redistribution of cold-water zooplankton species (Hays et al. 2005, Beaugrand et al. 2009), and could lead to major shifts in the location and strength of the principal Southern Ocean fronts (Bargagli 2005). These perturbations alter food-web structure at high latitudes with consequences for zooplanktivorous seabirds (Guinet et al. 1998, Fort et al. 2013), including alterations to both the phenology and direction of their migration (Quillfeldt et al. 2010, Thompson et al. 2012).

A number of studies have successfully reconstructed the ecological history of marine predators through the application of stable carbon and nitrogen isotope analysis, revealing long-term changes in diet and migration patterns in response to anthropogenic forcing (Hilton et al. 2006, Quillfeldt et al. 2010, Wiley et al. 2013, Bond \& Lavers 2014, Cherel et al. 2014). There is a broad latitudinal gradient in stable carbon isotope ratios of surface-water particulate organic matter in the Southern Ocean, with higher values in warmer subtropical waters and lower values in colder Antarctic waters (François et al. 1993, Trull \& Armand 2001). This latitudinal gradient is propagated through the food chain to higher trophic levels and has been used to predict foraging locations and to infer the migratory patterns of marine predators (Cherel et al. 2009, Phillips et al. 2009, Jaeger et al. 2010).

In this study, we focused on 2 small congeneric petrels: the broad-billed prion Pachyptila vittata and the Antarctic prion P. desolata. Broad-billed prions breed in large colonies close to the subtropical convergence on islands around New Zealand and in the central South Atlantic, whereas Antarctic prions have a more southerly circumpolar breeding distribution (Brooke 2004) but may winter as far north as $30^{\circ} \mathrm{S}$ (Quillfeldt et al. 2013). The 2 prion species differ in bill morphology; broad-billed prions are dietary specialists that feed predominantly on large copepods, whereas Antarctic prions feed on a wider range of small zooplankton taxa (Klages \& Cooper 1992, Brooke 2004).

To explore the responses of these 2 species to climate warming, we combined stable isotope analysis of feathers from museum skins with the deployment of miniaturised combined geolocation-immersion loggers. We first examined historical trends in carbon and nitrogen isotope ratios, then characterised the environmental conditions experienced by tracked individuals during migration. Using this information, we determined the extent to which these birds may have adjusted their migratory behaviour to match changes in the spatial distribution of their primary prey source. We discuss our results in the context of recent suggested poleward shifts in distribution of related species (Quillfeldt et al. 2010, Cherel et al. 2014).

\section{MATERIALS AND METHODS}

\section{Historical distributions}

We inferred historical migration destinations (latitude) from stable carbon isotope analysis of primary covert feathers sampled from study skins of adult prions held at the Museum of New Zealand Te Papa Tongarewa, Wellington. Prions undergo a complete moult of primary feathers during the non-breeding period, and primary coverts are usually moulted sequentially with the corresponding primary feather (Marchant \& Higgins 1990, Brooke 2004, Cherel et al. 2016). To limit damage, one primary covert from each museum skin was sampled. Feathers were taken 
from Antarctic prions collected during the breeding season on islands around Port Ross, Auckland Island $\left(50^{\circ} 32^{\prime} \mathrm{S}, 166^{\circ} 14^{\prime} \mathrm{E}\right)$ between 1942 and 1973, and broad-billed prions collected during the breeding season on the Snares $\left(48^{\circ} 02^{\prime} \mathrm{S}, 166^{\circ} 36^{\prime} \mathrm{E}\right)$, Stewart Island $\left(46^{\circ} 55^{\prime} \mathrm{S}, 167^{\circ} 55^{\prime} \mathrm{E}\right)$, and Rangatira (South East Island), Chatham Islands $\left(44^{\circ} 21^{\prime} \mathrm{S}, 176^{\circ} 10^{\prime}\right.$ W) between 1926 and 1986 (Table 1).

Museum specimen samples were complemented with primary coverts sampled from broad-billed prions collected on Rangatira in 2010, 2012 and 2013 by the authors (Table 1), and from Antarctic prions on, Adams Island, Auckland Islands in 2005. Broad-billed prions sampled in 2013 had been fitted with loggers in the previous season, and so were of known non-breeding distribution. Although feathers were also obtained from these individuals in 2012, the samples were excluded from analysis of long-term trends to avoid pseudoreplication. For Antarctic prions sampled in 2005, only body feathers were available. Body moult may begin at the end of the breeding season while birds are still attending the colony (Marchant \& Higgins 1990) and so, for these birds, we included the average value from 2 body feathers for each individual (Carravieri et al. 2014).

Stable isotope analysis of feather samples was conducted at the East Kilbride Node of the Natural Environment Research Council (NERC) Life Sciences Mass Spectrometry Facility via continuous flow isotope ratio mass spectrometry, using a ECS 4010 elemental analyser (Costech) interfaced with a Delta V plus mass spectrometer (Thermo Fisher Scientific). Stable isotope ratios are reported in $\delta$ notation, expressed as parts per thousand (\%) deviation according to the equation $\delta x=\left[\left(R_{\text {sample }} / R_{\text {standard }}\right)-1\right]$, where $x$ is ${ }^{13} \mathrm{C}$ or ${ }^{15} \mathrm{~N}, R$ is the corresponding ratio ${ }^{13} \mathrm{C} /{ }^{12} \mathrm{C}$ or ${ }^{15} \mathrm{~N} /{ }^{14} \mathrm{~N}$, and $R_{\text {standard }}$ is the ratio of the international references VPDB for carbon and AIR for nitrogen. Values were corrected by 3-point normalisation using Gel $\left(\delta^{15} \mathrm{~N}: 5.8 \%\right.$, $\delta^{13} \mathrm{C}:-20.2 \%$; $\left.24 \mathrm{run}^{-1}\right)$, Alagel (an alanine-gelatin solution; $\delta^{15} \mathrm{~N}: 2.6 \%$, $\delta^{13} \mathrm{C}:-9.0 \%$; $10 \mathrm{run}^{-1}$ ) and Glycine $\left(\delta^{15} \mathrm{~N}: 19.8 \%\right.$, $\delta^{13} \mathrm{C}:-36.2 \%$; $\left.10 \mathrm{run}^{-1}\right)$. The measurement precision, calculated as the standard deviation of quadruplicate analyses of tryptophan in each run, was $\pm 0.1 \%$ for both $\delta^{13} \mathrm{C}$ and $\delta^{15} \mathrm{~N}$.
Burning of fossil fuels since the industrial revolution has led to a global decrease in ${ }^{14} \mathrm{C}$ in atmospheric $\mathrm{CO}_{2}$ (Suess 1955, Keeling 1979, Sonnerup et al. 1999). The ocean $\delta^{13} \mathrm{C}$ Suess effect can be described as a $0.007 \% \mathrm{yr}^{-1}$ decline between 1860 and 1970, and a steeper $0.018 \%$ o $\mathrm{yr}^{-1}$ decline from 1970 onward (Tagliabue \& Bopp 2008). We adjusted our historical samples relative to the youngest samples in our dataset (2013), using the following equations.

$$
\text { If } t_{i} \geq 1970 \text {, then: }
$$

$$
\delta^{13} \mathrm{C}_{\mathrm{adj}}=\delta^{13} \mathrm{C}_{\mathrm{raw}}-0.018 \times\left(2013-t_{i}\right)
$$

If $t_{i}<1970$, then:

$$
\begin{aligned}
\delta^{13} \mathrm{C}_{\mathrm{adj}}= & \delta^{13} \mathrm{C}_{\mathrm{raw}}-0.018 \times(2013-1970) \\
& +0.007 \times\left(1970-t_{i}\right)
\end{aligned}
$$

where $t_{i}$ represents a given year from the dataset.

This had the effect of reducing $\delta^{13} \mathrm{C}$ values in the oldest samples (1926) relative to the youngest samples (2013) by a maximum of $1.082 \%$. We did not adjust $\delta^{13} \mathrm{C}$ values for changes in ocean $\left[\mathrm{CO}_{2}\right]_{\mathrm{aq}}$ due to anthropogenic carbon emissions, as the magnitude of this effect is small relative to the analytical error of our measurements (Hilton et al. 2006, Quillfeldt et al. 2010, Fairhurst et al. 2015). 


\section{Contemporary distributions}

In October 2012, we deployed 20 Mk 4093 (1.5 g) and $11 \mathrm{Mk} 3006$ (2.5 g) combined geolocationimmersion loggers (Biotrack) on breeding adult broad-billed prions caught when attending burrows on Rangatira. Devices represented $<1.5 \%$ of mean body mass $(190 \mathrm{~g})$. Loggers were programmed to sample light every $1 \mathrm{~min}$ and record the maximum value in each $5 \mathrm{~min}$ (Mk 4093) or $10 \mathrm{~min}$ (Mk 3006) interval. In addition, the devices tested for saltwater immersion every $3 \mathrm{~s}$ and recorded the sum of positive tests every $10 \mathrm{~min}$. In October 2013, we recovered 20 loggers $(65 \%)$ containing data for the complete annual cycle. A further logger was recovered in March 2014 with data for 2 non-breeding periods.

Light data were processed following standard methods (Wilson et al. 1992). Briefly, the timings of sunset and sunrise were estimated according to set thresholds in light curves; latitude derived from day length, and longitude from the timing of local midday and midnight, with respect to Greenwich Mean Time and Julian day. This provided 2 positions $\mathrm{d}^{-1}$ with an accuracy of approximately $200 \mathrm{~km}$ (Phillips et al. 2004). However, around the vernal and autumnal equinoxes, day and night are of equal length and so it becomes impossible to estimate latitude. Light curves were analysed using TransEdit and BirdTracker software packages (BAS) using a threshold of 10 and an elevation angle of $-3.5^{\circ}$, based on data obtained during the breeding season when the birds were close to the colony. We removed obviously erroneous locations associated with interference in light curves (caused by shading) around the time of sunset and sunrise, and used a speed filter to limit sustained movement to $480 \mathrm{~km}$ in a $24 \mathrm{~h}$ period $\left(20 \mathrm{~km} \mathrm{~h}^{-1}\right)$.

By combining the estimated sunrise and sunset times with the immersion data, we calculated the proportion of daylight hours spent on the water and matched this with the location data to provide information on at-sea activity patterns throughout the annual cycle. Birds have reduced flight ability during moult, and so extended periods on the water surface during the day may indicate moulting areas. We classified departure from the colony on migration as the date that an individual moved beyond a range of $500 \mathrm{~km}$ from the colony. Arrival at the colony was estimated by examining light and activity data to determine the first day an individual spent in the nesting burrow on return from the non-breeding grounds.

\section{Environmental data}

To quantify the marine habitat that broad-billed prions use during the non-breeding period, we extracted a range of environmental datasets. Global gridded bathymetry data were obtained from the NERC British Oceanographic Data Centre General Bathymetric Chart of the Oceans (GEBCO; https:// www.gebco.net) at $1 \mathrm{~min}$ resolution and bilinearly interpolated to $2 \mathrm{~km}^{2}$ resolution. Information on the location of seamounts was taken from the Global Seamount Database (Wessel 2001). Assuming all seamounts are conical frustums, we calculated the volume $V$ of each using the following equation:

$$
V=\frac{\pi h}{3}\left(R^{2}+R r+r^{2}\right)
$$

where $h=$ height, $R=$ radius of base, and $r=$ radius of top.

We then extracted the locations of the top $25 \%$ of seamounts by volume $\left(>1092 \mathrm{~km}^{3}\right)$, as these are likely to generate the largest upwellings, and used these locations to generate a grid of distance to nearest seamount at the same $2 \mathrm{~km}^{2}$ resolution. We extracted global monthly chlorophyll a ( chl a) and sea surface temperature (SST; $11 \mu$ night-time) composite data at $4 \mathrm{~km}^{2}$ resolution from the MODIS instrument on board the Aqua (EOS PM) satellite (http://ocean color.gsfc.nasa.gov/). All data were projected to a custom Lambert azimuthal equal area projection centred on the Rangatira breeding colony using ArcGIS 10.0 (ESRI).

\section{Statistical analysis}

We examined potential shifts in stable isotope signatures over time using either $\delta^{15} \mathrm{~N}$ or $\delta^{13} \mathrm{C}_{\text {adj }}$ as the response variable in a linear regression with year and species as fixed effects, and the interaction between year and species included to explore speciesspecific differences over time. Due to heterogeneity of variance, models were fitted using generalised least squares with a species by year-specific variance structure in the package 'nlme' (Pinheiro et al. 2014). We estimated the goodness-of-fit of final models by calculating Nagelkerke's pseudo- $\mathrm{R}^{2}$ using the package 'MuMIn' (Bartoń 2015).

Non-breeding distributions were identified using the bivariate normal kernel utilisation distribution of the locations from all tracked individuals, using a smoothing parameter (h) of $200 \mathrm{~km}$ and a grid size of $50 \mathrm{~km}$, implemented in the package 'adehabitatHR' 
(Calenge 2006). Changes in activity linked to moult during the non-breeding period were examined by fitting the proportion of daylight hours that an individual spent on the water per day as the response (logit transformed) in a generalised linear mixed model (GLMM) fitted using the package 'Ime4' v.1.1-10 (Bates et al. 2015) with Bird ID as a random intercept, and a Gaussian family. The time an individual spends on the water may peak during the non-breeding period as the outer primaries are moulted (reducing flight ability), and so we also included the second order polynomial of day-of-year as a fixed effect.

We took a use-availability approach to examine habitat use during the non-breeding period and fitted logistic regressions using the presence data from the geolocation fixes in combination with pseudoabsences generated randomly from across the species range at a 5:1 absence to presence ratio. To account for the error in geolocation and provide a better understanding of habitat use, we generated 50 random points around each presence or pseudoabsence from a bivariate Gaussian distribution with a mean equal to the estimated location, and standard deviations equal to $50 \mathrm{~km}$ on the $x$ - and $100 \mathrm{~km}$ on the $y$-axis. In this way, $95 \%$ of the random points were within 100 and $200 \mathrm{~km}$ of the estimated location on the $x$ - and $y$-axes respectively. This is approximately the error in the location (Phillips et al. 2004). We then extracted the mean of the environmental variable sampled by each set of 50 random points. All explanatory covariates were standardised by subtracting the mean and dividing by the standard deviation. We assessed multicollinearity using variance inflation factors (VIFs) and pairwise plots, and subsequently removed chl a from our analyses. Once removed, all VIFs $<3$. Models were fitted as binomial GLMMs using the package 'Ime4' v.1.0 (Bates et al. 2015) with depth, SST, distance to breeding colony and distance to seamount as fixed effects, and Bird ID as a random intercept. We included the second-order polynomial of depth and temperature as fixed effects to allow for an optimum depth or temperature preference during the non-breeding period.

We examined goodness-of-fit of the final model using a confusion matrix to compare the binary predictions with the observed presence and absences in the dataset. We also tested receiver operating characteristic (ROC) curves and calculated the associated area under the ROC curve (AUC) as a further measure of model performance. To provide an estimate of model fit, we extracted final model variance components and, following Nakagawa \& Schielzeth (2013), we present the proportion of variance explained by the fixed effects as the marginal $R^{2}, R^{2}{ }_{\text {GLMM(m) }}$, and the proportion of variance explained by both the fixed and random components as the conditional $R^{2}$, $R_{\text {GLMM(c). }}^{2}$.

Finally, to test for consistency of habitat use by individuals in consecutive non-breeding periods, we calculated the repeatability of $\delta^{13} \mathrm{C}$ and $\delta^{15} \mathrm{~N}$ in feathers of tracked individuals $(n=23)$ from which we obtained samples in both 2012 and 2013, using the package 'rptR' (Nakagawa \& Schielzeth 2010). This provides a measure of between-year repeatability (r) with associated $95 \%$ confidence intervals and pvalue. Unless indicated otherwise, means are provided $\pm \mathrm{SD}$. All analyses were conducted using $\mathrm{R}$ v.3.2.2 (R Core Team 2015).

\section{RESULTS}

\section{Historical stable isotope ratios}

There was a significant difference between species in the changes in feather $\delta^{13} \mathrm{C}$ over time $\left(\chi^{2}=10.05, \mathrm{p}\right.$ $=0.002$; Nagelkerke $\left.\mathrm{R}^{2}=53.8 \%\right) \cdot \delta^{13} \mathrm{C}$ in feathers of Antarctic prions from the Auckland Islands declined significantly between 1942 and 2005 (year slope = $-0.03 \pm 0.01 \%$; Fig. 1a), but there was no detectable change in feathers of broad-billed prions from colonies around New Zealand between 1926 and 2013 (year slope $=0.00 \pm 0.01 \%$; Fig. 1a). In contrast, feathers from both species exhibited a decline in $\delta^{15} \mathrm{~N}$ over the study period, although the slopes differed $\left(\chi^{2}=4.18, \mathrm{p}=0.041\right.$; Nagelkerke $\left.\mathrm{R}^{2}=18.1 \%\right)$; the decrease was much steeper in Antarctic prions (year slope $=-0.06 \pm 0.02 \%$; Fig. 1b) than broad-billed prions (year slope $=-0.02 \pm 0.02 \%$; Fig. 1b).

\section{Contemporary non-breeding distributions}

The mean date of post-breeding departure from Rangatira for broad-billed prions tracked with geolocator-immersion loggers was 22 December $2012( \pm 16.8 \mathrm{~d})$ and arrival back in the burrow was 8 March $2013( \pm 11.2$ d), with birds spending on average $76.4 \pm 12.5 \mathrm{~d}$ away from the colony. Movement away from the breeding colony was concurrent with an increase in the proportion of daylight hours that individuals spent on the water (Fig. 2). This was best explained by a quadratic effect of day-of-year, as time on the water increased gradually from the early to mid-non-breeding period $\left(\chi^{2}=125.42, \mathrm{p}<0.001\right)$, peaked around late January, then declined gradually 


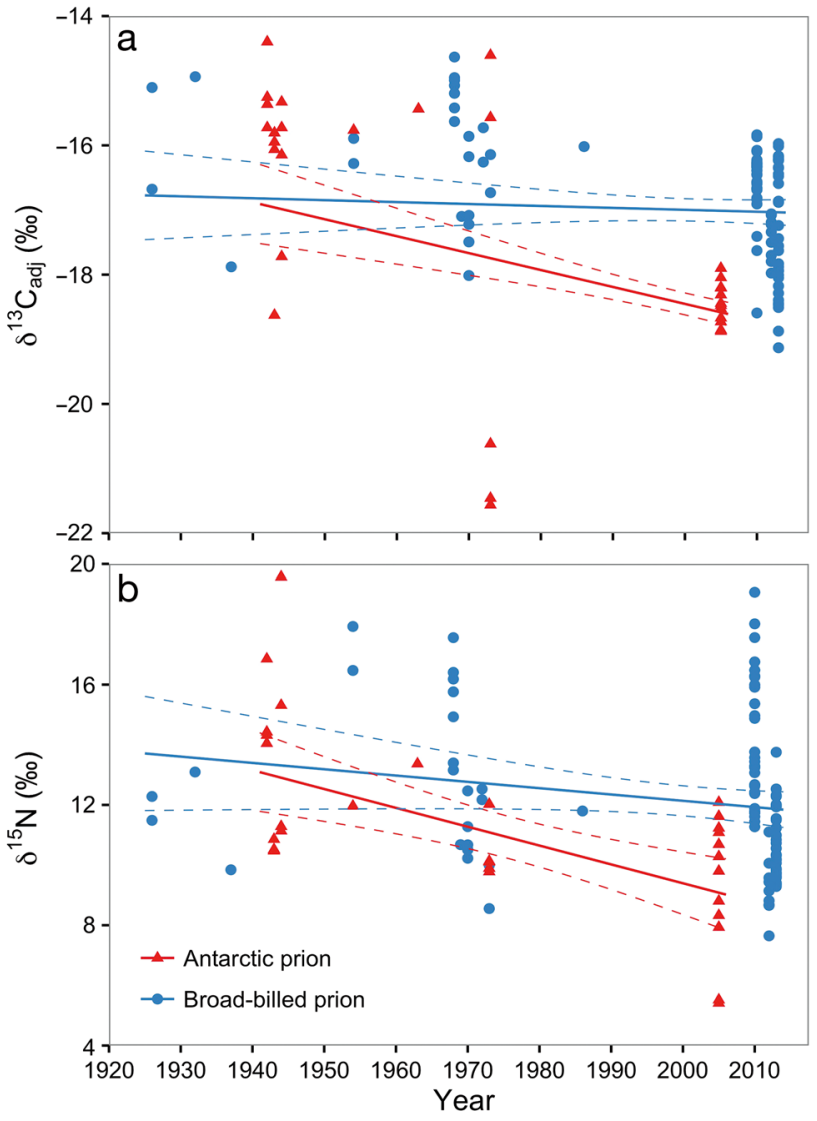

Fig. 1. Time series of stable isotope ratios in feathers of Antarctic prions Pachyptila desolata and broad-billed prions $P$. vittata sampled at colonies around New Zealand. The fitted linear trends predicted from generalised least squares regression (solid lines) are presented with 95\% confidence intervals (dashed lines) for (a) $\delta^{13} \mathrm{C}$ adjusted for the Suess effect, and (b) $\delta^{15} \mathrm{~N}$

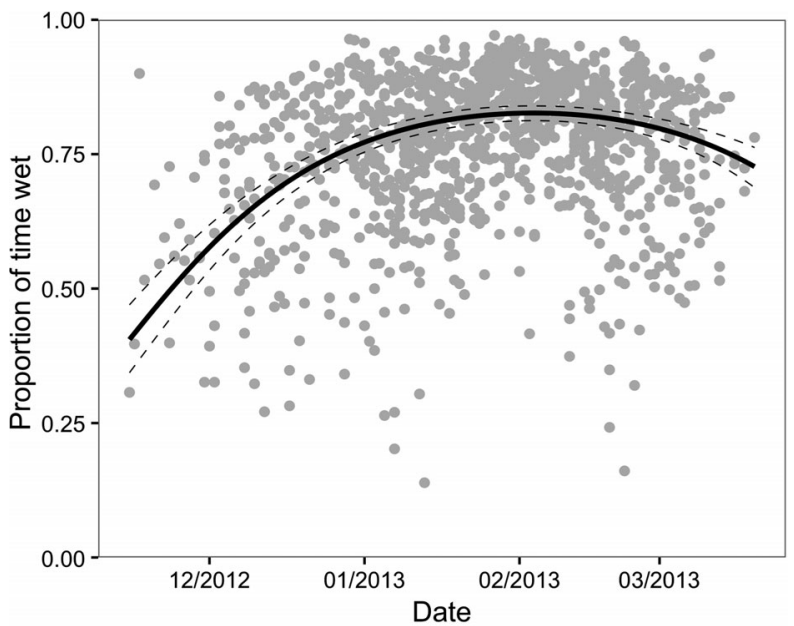

Fig. 2. Trend in the proportion of daylight hours spent on the water by 20 adult broad-billed prions Pachyptila vittata tracked using geolocator-immersion loggers from Rangatira, New Zealand (light grey dots). Fitted population values from a linear mixed-effects model (solid line) with 95\% confidence intervals (dotted lines) in the last month or so before birds returned to the colony $\left(\chi^{2}=129.21, \mathrm{p}<0.001\right.$; Fig. 2$)$.

During the non-breeding period, all tracked birds migrated ca. $1000 \mathrm{~km}$ to the east of the breeding colony (Fig. 3) and the probability of occurrence declined with distance from the colony $\left(\chi^{2}=713.83\right.$, $\mathrm{p}<0.001$; Fig. 4). Broad-billed prions were more likely to occur close to seamounts $\left(\chi^{2}=480.05\right.$, $p<$ 0.001; Fig. 4); the non-breeding area was bisected north-south by the Louisville seamount chain and east-west by the subtropical front (Fig. 3). This is a region of deep water interrupted by the longest seamount chain in the South Pacific Ocean, which extends up to $7300 \mathrm{~m}$ above the sea floor, transverse to the subtropical front and prevailing oceanic currents. Consequently, broad-billed prions occurred over deeper water $\left(\chi^{2}=318.73, \mathrm{p}<0.001\right.$; quadratic effect $\chi^{2}=17.00, p<0.001$; Fig. 4). Broad-billed prion occurrence also correlated with SST $\left(\chi^{2}=27.54, \mathrm{p}<\right.$ $0.001)$, with the inclusion of the quadratic term $\left(\chi^{2}=\right.$ 250.33, p < 0.001) indicating birds occurred most often over waters of approximately $15^{\circ} \mathrm{C}$, although the effect size was small (Figs. $3 \& 4$ ). Validation of the habitat preference model confirmed the final model fitted the data acceptably well (AUC $=0.97$ ). The true positive rate obtained from the confusion matrix was $96.7 \%$, and the observed accuracy was $90.5 \%$. Overall, the model explained a large proportion of the variance $\left(R_{\mathrm{GLMM}(\mathrm{c})}^{2}=94.50 \%, R_{\mathrm{GLMM}(\mathrm{m})}^{2}=\right.$ $94.46 \%)$.

Comparison of stable isotope ratios in feathers from the broad-billed prions sampled in 2 consecutive seasons at Rangatira revealed no repeatability in either $\delta^{13} \mathrm{C}(\mathrm{r}=0.00,95 \%$ CI $[0.00,0.388], \mathrm{p}=0.616)$, or $\delta^{15} \mathrm{~N}$ $(\mathrm{r}=0.00,95 \%$ CI $[0.00,0.382], \mathrm{p}=0.627)$, with values shifting by up to $2 \%$ in $\delta^{13} \mathrm{C}$ (mean $=0.9 \pm 0.5 \%$ ) and $3.2 \%$ in $\delta^{15} \mathrm{~N}$ (mean $=1.5 \pm 0.9 \%$ ) from one year to the next (Fig. 5). The range in values (considering data from both years) was much larger in $\delta^{15} \mathrm{~N}$ than $\delta^{13} \mathrm{C}$ ( 7.7 to $13.8 \%$ vs. -19.1 to $-16.0 \%$ ). The narrow range of ${ }^{13} \mathrm{C}$ values implies a narrow range of latitudes used by the birds during the non-breeding season, consistent with the results obtained from the geolocators.

\section{DISCUSSION}

In this study, we revealed differential patterns in feather stable isotope ratios between 2 congeneric marine predators. Analysis of stable isotope ratios revealed a long-term decline in $\delta^{13} \mathrm{C}$ in feathers of Antarctic prion (but not broad-billed prion) from 
colonies around New Zealand. Both species exhibited a long-term decline in feather $\delta^{15} \mathrm{~N}$ during the study period. Data from tracked individuals indicated that broad-billed prions migrate east from the breeding colony to an area where the Louisville seamount chain bisects the subtropical front.

\section{Historical distributions inferred from stable isotope ratios}

The analysis of historical specimens revealed that $\delta^{13} \mathrm{C}$ values of Antarctic prion feathers declined significantly over 6 decades, while those of broad-billed prions did not. There are 3 non-exclusive explanations that may account for these trends: (1) changes to isotopic baselines, (2) changes to prey communities, and (3) changes in non-breeding distribution. We discuss these below.

In the Southern Ocean, spatial heterogeneity in atmospheric circulation, reflected in the Southern Annular Mode and El Niño Southern Oscillation, are associated with changes in SST, sea ice cover and eddy kinetic energy (Hall \& Visbeck 2002, Sallée et al. 2010). As phytoplankton growth rate is linked to carbon fractionation (Laws et al. 1995), declines in primary productivity lower baseline $\delta^{13} \mathrm{C}$ and may propagate to organisms at higher trophic levels (Schell 2000, Jaeger \& Cherel 2011). Therefore, changes in $\delta^{13} \mathrm{C}$ may reflect a general decline in ocean primary production, or differing productivity regimes that vary over decadal time scales, as seen in rockhopper penguins Eudyptes chrysocome (Hilton et al. 2006). However, if the observed declines in $\delta^{13} \mathrm{C}$ were due to shifts in baseline productivity, we might expect the trend to be mirrored in the historical feather $\delta^{13} \mathrm{C}$ values of broad-billed prions as well as Antarctic prions, which was not the case.

Despite the divergence in $\delta^{13} \mathrm{C}$, both species showed a decline in $\delta^{15} \mathrm{~N}$ in feathers over the study period, equating to an estimated reduction of $0.63 \%$ o decade ${ }^{-1}$ for Antarctic prions (-3.97\%o over $63 \mathrm{yr}$ ), and of

Fig. 3. Non-breeding distribution of 20 adult broad-billed prions Pachyptila vittata tracked using geolocator-immersion loggers from November 2012 to March 2013 from a breeding colony on Rangatira, New Zealand (black star), illustrated by (a) the $25,50,75$ and $95 \%$ contours of a bivariate normal kernel utilisation distribution. Locations of the sub-tropical front (STF) and sub-Antarctic front (SAF) taken from Orsi et al. (1995). (b) The bathymetry of this region with the location of large seamounts (black dots) including the Louisville seamount chain. (c) Mean sea surface temperature for the study period (November 2012 to March 2013)
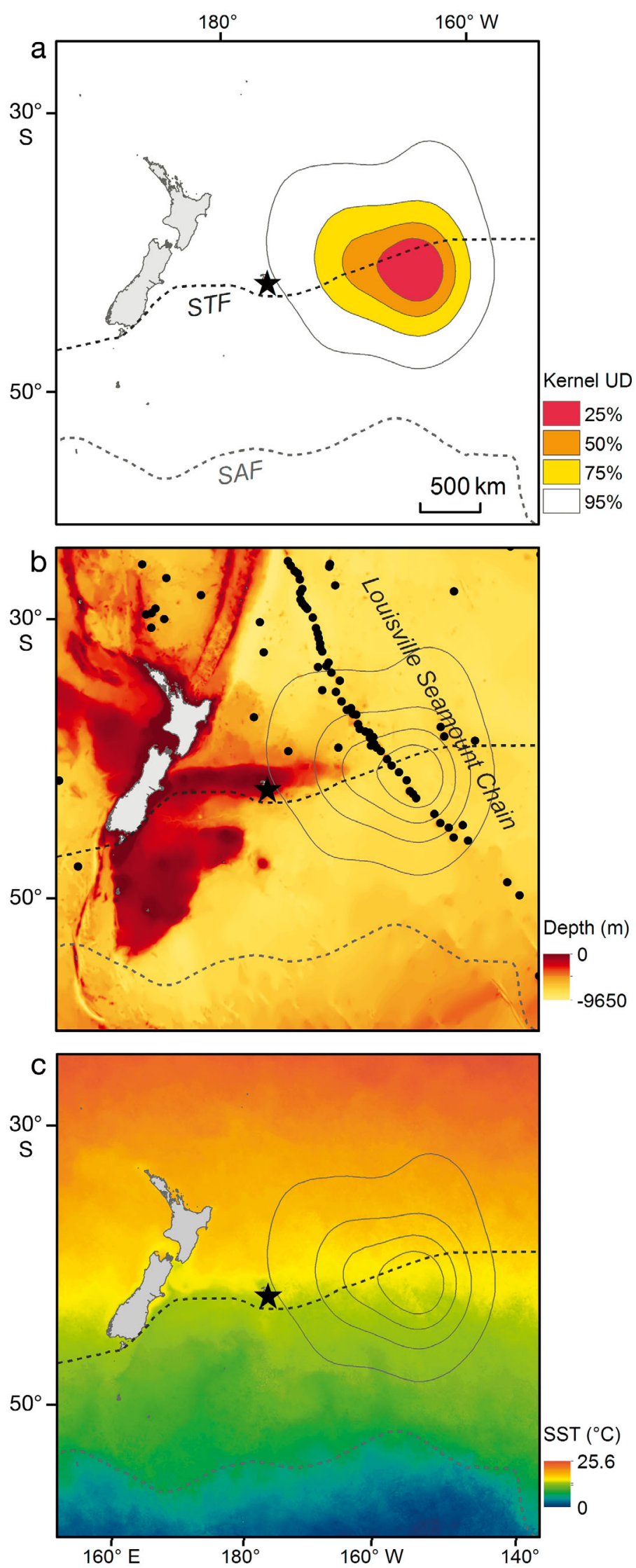

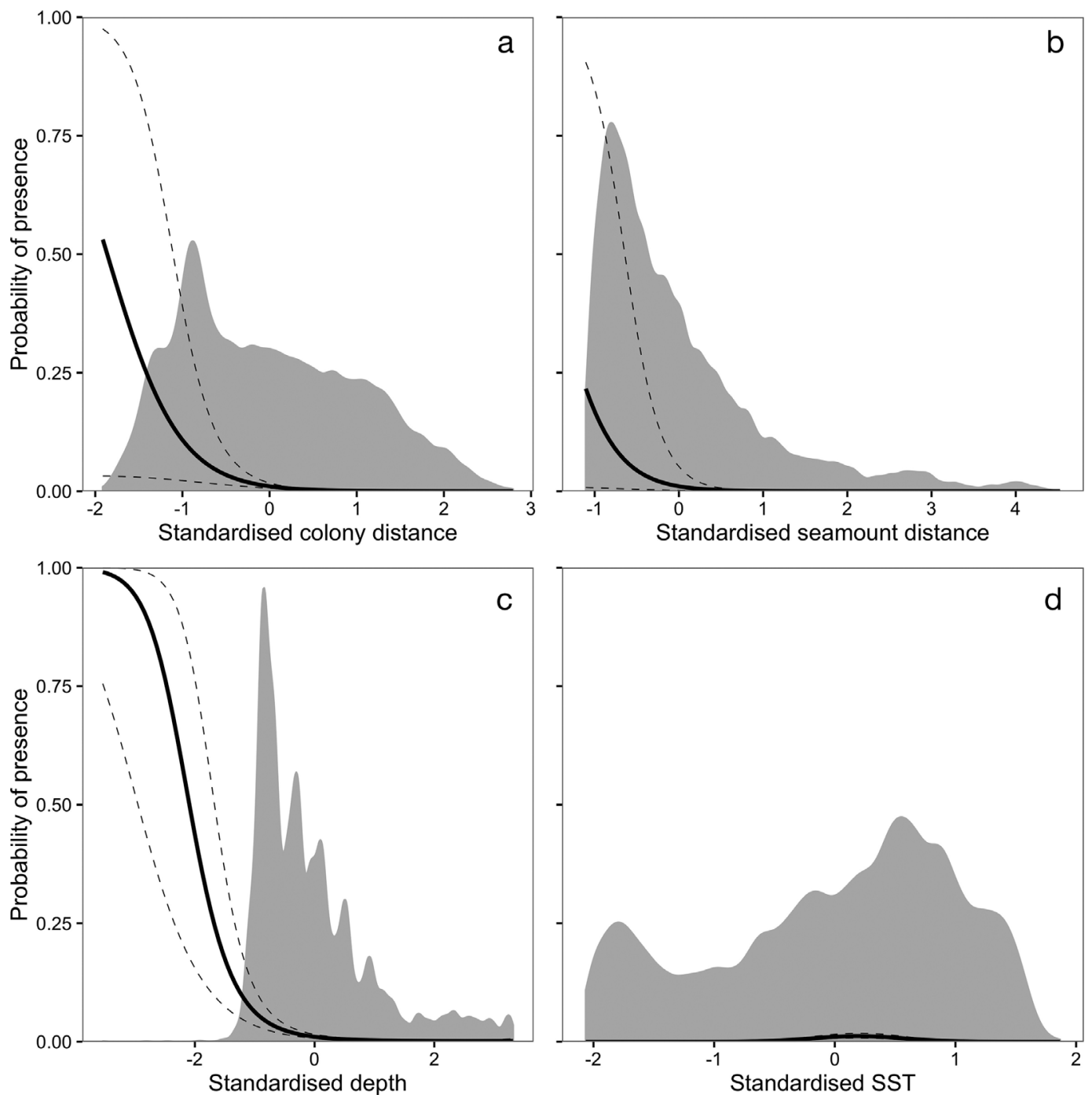

Fig. 4. Modelled relationship between standardised environmental variables: (a) distance to colony, (b) distance to seamounts, (c) depth and (d) sea surface temperature (SST), and the presence of broad-billed prions Pachyptila vittata in the non-breeding

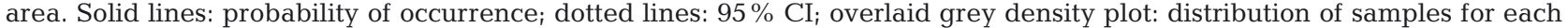
environmental parameter

$0.21 \%$ decade $^{-1}$ for broad-billed prions $(-1.83 \%$ over $87 \mathrm{yr})$. In general, $\delta^{15} \mathrm{~N}$ shows a step-wise enrichment of 3 to $5 \%$ with each trophic level (Hobson \& Welch 1992), and so these declines in $\delta^{15} \mathrm{~N}$ could indicate a change in prey communities, trophic structure or a shift to lower trophic prey. The southern Indian Ocean experienced an atmospheric temperature-defined regime shift in the $1970 \mathrm{~s}$, which reduced the abundance of zooplankton and had negative impacts on many marine vertebrate populations (Weimerskirch et al. 2003). The declines we detected in $\delta^{15} \mathrm{~N}$ could therefore be due to changes in prey communities, particularly zooplankton. In this case, differences detected between Antarctic and broad-billed prion may be due to differences in prey choice, as the latter specialises in large copepods, whereas the former has a more generalist diet.

Given the broad latitudinal gradient in stable carbon isotope ratios of surface-water particulate organic matter in the Southern Ocean (François et al. 1993, Trull \& Armand 2001), a general population-level decline $\left(-0.26 \%\right.$ decade $\left.{ }^{-1}\right)$ in feather $\delta^{13} \mathrm{C}$ of Antarctic prions between 1942 and 2005 may be indicative of a southward shift in non-breeding distribution toward higher latitudes. In this case, the lack of a concurrent change in $\delta^{13} \mathrm{C}$ of broad-billed prions would suggest this species has not shifted nonbreeding latitudes, although distances between the breeding colonies included in this study were ca. $1500 \mathrm{~km}$. Overlap in $\delta^{13} \mathrm{C}$ of samples from both prion 


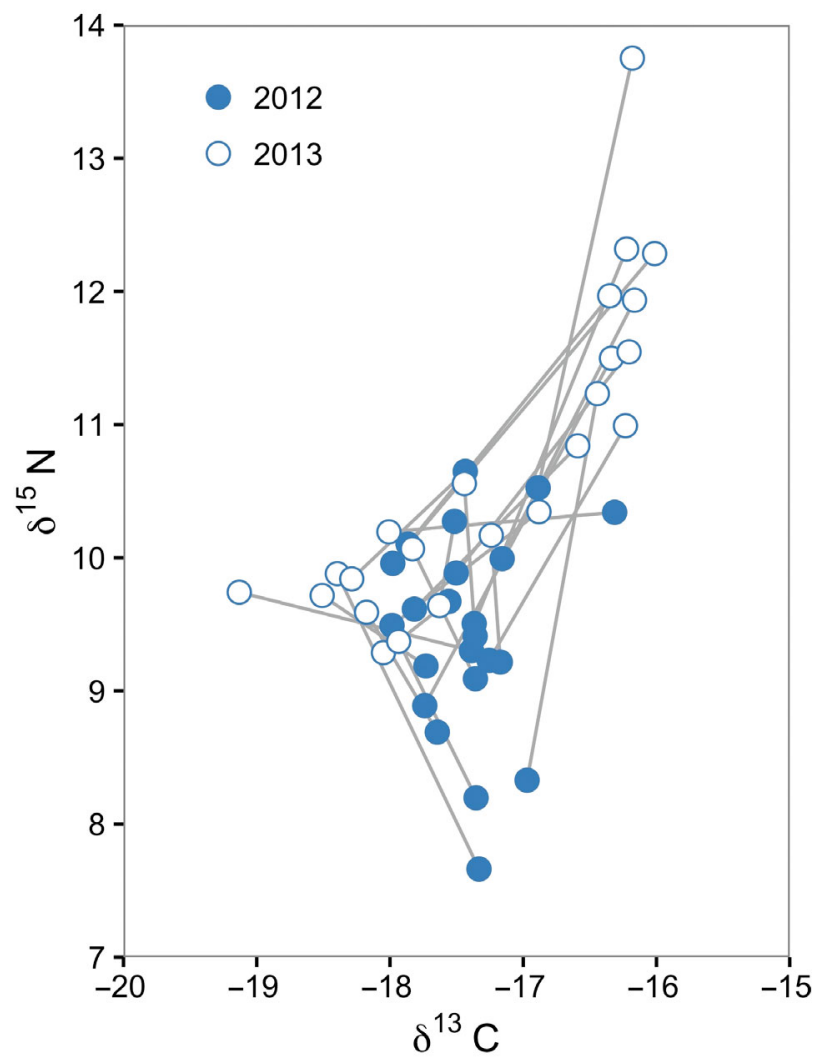

Fig. 5. Annual variation in $\delta^{13} \mathrm{C}$ and $\delta^{15} \mathrm{~N}$ in feathers of 23 adult broad-billed prions Pachyptila vittata from Rangatira Island, New Zealand, sampled in 2012 and 2013. The 2 samples from each individual are connected by a grey line

species collected before 1970 could therefore be the result of historically shared non-breeding latitudes, with the subsequent decrease in Antarctic prion $\delta^{13} \mathrm{C}$ indicating non-breeding distributions have since moved south of the subtropical front (Phillips et al. 2009).

In the western South Atlantic, recent tracking indicates that while the non-breeding distribution of Antarctic prions extends from Antarctic to subtropical waters, the majority of birds use sub-Antarctic waters between the sub-Antarctic and subtropical fronts (Quillfeldt et al. 2013, 2015). In the western South Pacific, the sub-Antarctic front is situated ca. $1500 \mathrm{~km}$ to the south of the subtropical front (Fig. 2). The differences we detected in isotope ratios suggest that Antarctic prions may target the same water mass in the western South Pacific. Both carbon and nitrogen baselines may change with latitude, and recent studies have also demonstrated a pronounced temporal shift in $\delta^{13} \mathrm{C}$ and $\delta^{15} \mathrm{~N}$ in feathers of thin-billed prion $P$. belcheri, indicating a southerly shift of the main moulting areas toward higher latitudes (Quill- feldt et al. 2010, Cherel et al. 2014). Nevertheless, without independent information on isotopic baselines or diet, it is impossible to disentangle the extent to which each of these 3 hypotheses may explain the patterns we detected.

\section{Contemporary distributions from tracking data}

All tracked broad-billed prions migrated ca. 1000 $\mathrm{km}$ east from the breeding colony on Rangatira, and spent the non-breeding period in a relatively small area where the subtropical front bisects the southern end of the Louisville seamount chain. Immersion data indicate that birds increased the amount of time they spent on the water during daylight once they arrived in this area, suggesting that it is the main moulting site for this population (Fig. 2).

Although the latitude of the subtropical front can vary seasonally across the Southern Ocean (Graham \& De Boer 2013), the underlying bathymetry of the Chatham Rise fixes its position to the east of New Zealand (Sutton 2001, Smith 2013) and may have done so throughout the Quaternary glaciations when the temperature gradient across the front was stronger, and productivity greater (Heath 1981, Weaver et al. 1998). Topographically driven upwellings, generated through the interaction between eastwardflowing currents and large-scale bathymetric features such as the Louisville seamount chain are therefore likely to be stable and predictable features (Heath 1981). In the north-east Pacific, high densities of Neocalanus cristatus around seamounts are positively correlated with elevated densities of Cassin's auklet Ptychoramphus aleuticus (Vermeer et al. 1985). Cooler, nutrient-rich water cycled to the surface fuels plankton blooms, and upwellings force zooplankton to surface waters and concentrate vertically migrating organisms into subsurface patches (Hyrenbach et al. 2000).

The Louisville seamount chain is unique in the southwest Pacific region as the only feature between the New Zealand Plateau and the East Pacific Rise that penetrates the upper bathyal zone. A range of marine top predators, including seabirds, are known to aggregate around seamounts, which represent biodiversity hotspots (Worm et al. 2003, Thompson 2007). This has implications for conservation management, as many seamounts face increasing anthropogenic threats, including from fishing (Pitcher et al. 2010), and so require protection (Penney et al. 2009).

The range in $\delta^{13} \mathrm{C}$ values of broad-billed prion feathers overlapped between years, and one tracked 
bird returned to the region of the Louisville seamount chain in 2 successive non-breeding periods (W. J. Grecian et al. unpubl. data), suggesting a degree of large-scale site fidelity. Nevertheless, stable isotope ratios in feathers collected in consecutive years were not repeatable. While birds may return to the same general region, there may be smaller-scale differences in foraging areas or habitat use, prey stable isotope ratios may be variable across the subtropical front, or individuals may target different resources across years.

\section{Implications}

Museum specimens offer a useful resource for forensic reconstructions of historical patterns in diet and distribution, providing a baseline with which to compare results from contemporary sampling. In this study, we describe a long-term decline in feather $\delta^{13} \mathrm{C}$ of Antarctic prions that suggests a response to climate-induced prey shifts in the form of a poleward movement during the non-breeding period. This supports previous findings in other prion species (Quillfeldt et al. 2010, Cherel et al. 2014). However, these results contrast with those for the broad-billed prion, which did not exhibit a detectable shift in feather $\delta^{13} \mathrm{C}$ in the period for which samples were available.

The tracking data indicate that broad-billed prions from the Chatham Islands utilise an upwelling area around the Louisville seamount chain during the non-breeding period. Topographically driven upwellings are stable and predictable features that may aggregate plankton (Vermeer et al. 1985). In this way, targeting seamounts could mitigate the impact of climate-induced prey shifts by providing refugia for this planktivorous specialist. Nevertheless, range shifts are known to occur as step changes rather than gradual transitions (Beaugrand 2004), and there may be a temperature threshold that determines copepod availability. This population of broad-billed prions may therefore be dependent on this upwelling feature and, if this refuge disappears, become isolated from prey aggregations further south with limited capacity to adapt.

Acknowledgements. Fieldwork on Rangatira was conducted with the permission and cooperation of the NZ Department for Conservation and would not have been possible without the support of the Chatham Island Area Office. Sampling of museum specimens was approved by Museum of New Zealand Te Papa Tongarewa and consisted of broad-billed prion OR.001846, OR.001850, OR.010458, OR.010459, OR.
013538-OR.013544, OR.015445-OR.015450, OR.015456, OR. 016655, OR.016656, OR.017461, OR.017677, OR.022320, OR.025858 and OR.026076; and Antarctic prion OR.008378, OR.010065, OR.013020, OR.013023, OR.013025, OR.013027OR.013029, OR.013032, OR.013034-OR.013038 and OR. 018142-OR.018146. We thank Dave Houston for collecting broad-billed prion feathers from Rangatira in 2010, and both Paul Johnson and Jason Matthiopoulos for statistical advice. This study represents a contribution to the Ecosystems component of the British Antarctic Survey Polar Science for Planet Earth Programme, funded by The Natural Environment Research Council. W.J.G. was funded by a NERC standard grant NE/I02237X/1.

\section{LITERATURE CITED}

Bargagli R (2005) Antarctic ecosystems, environmental contamination, climate change, and human impact. Springer, Berlin

Bartoń K (2015) MuMIn: multi-model inference. R package version 1.15.6. https://CRAN.R-project.org/package= MuMIn

Bates D, Maechler M, Bolker BM, Walker S (2015) Fitting linear mixed-effects models using lme4. J Stat Softw $67: 1-48$

Beaugrand G (2004) The North Sea regime shift: evidence, causes, mechanisms and consequences. Prog Oceanogr 60:245-262

Beaugrand G, Reid PC, Ibañez F, Lindley JA, Edwards M (2002) Reorganization of North Atlantic marine copepod biodiversity and climate. Science 296:1692-1694

> Beaugrand G, Luczak C, Edwards M (2009) Rapid biogeographical plankton shifts in the North Atlantic Ocean. Glob Change Biol 15:1790-1803

- Beaugrand G, Goberville E, Luczak C, Kirby RR (2014) Marine biological shifts and climate. Proc R Soc B 281: 20133350

Bond AL, Lavers JL (2014) Climate change alters the trophic niche of a declining apex marine predator. Glob Change Biol 20:2100-2107

Boyce DG, Lewis MR, Worm B (2010) Global phytoplankton decline over the past century. Nature 466:591-596

Bradford-Grieve JM, Boyd PW, Chang FH, Chiswell S and others (1999) Pelagic ecosystem structure and functioning in the subtropical front region east of New Zealand in austral winter and spring 1993. J Plankton Res 21:405-428

Brooke M (2004) Albatrosses and petrels across the world. Oxford University Press, Oxford

Calenge C (2006) The package 'adehabitat' for the R software: a tool for the analysis of space and habitat use by animals. Ecol Modell 197:516-519

> Carravieri A, Bustamante P, Churlaud C, Fromant A, Cherel Y (2014) Moulting patterns drive within-individual variations of stable isotopes and mercury in seabird body feathers: implications for monitoring of the marine environment. Mar Biol 161:963-968

> Chen IC, Hill JK, Ohlemüller R, Roy DB, Thomas CD (2011) Rapid range shifts of species associated with high levels of climate warming. Science 333:1024-1026

> Cherel Y, Connan M, Jaeger A, Richard P (2014) Seabird year-round and historical feeding ecology: blood and feather $\delta^{13} \mathrm{C}$ and $\delta^{15} \mathrm{~N}$ values document foraging plasticity of small sympatric petrels. Mar Ecol Prog Ser 505: $267-280$ 
Cherel Y, Kernaléguen L, Richard P, Guinet C (2009) Whisker isotopic signature depicts migration patterns and multi-year intra- and inter-individual foraging strategies in fur seals. Biol Lett 5:830-832

Cherel Y, Quillfeldt P, Delord K, Weimerskirch H (2016) Combination of at-sea activity, geolocation and feather stable isotopes documents where and when seabirds moult. Front Ecol Environ 4:3

Cotton PA (2003) Avian migration phenology and global climate change. Proc Natl Acad Sci USA 100:12219-12222

Edwards M, Richardson AJ (2004) Impact of climate change on marine pelagic phenology and trophic mismatch. Nature 430:881-884

Egevang C, Stenhouse IJ, Phillips RA, Petersen A, Fox JW, Silk JRD (2010) Tracking of Arctic terns Sterna paradisaea reveals longest animal migration. Proc Natl Acad Sci USA 107:2078-2081

> Fairhurst GD, Bond AL, Hobson KA, Ronconi RA (2015) Feather-based measures of stable isotopes and corticosterone reveal a relationship between trophic position and physiology in a pelagic seabird over a 153-year period. Ibis 157:273-283

> Fort J, Moe B, Strøm H, Grémillet D and others (2013) Multicolony tracking reveals potential threats to little auks wintering in the North Atlantic from marine pollution and shrinking sea ice cover. Divers Distrib 19:1322-1332

- François R, Altabet MA, Goericke R, McCorkle DC, Brunet C, Poisson A (1993) Changes in the $\delta^{13} \mathrm{C}$ of surface water particulate organic matter across the subtropical convergence in the SW Indian Ocean. Global Biogeochem Cycles 7:627-644

Gill JA, Alves JA, Sutherland WJ, Appleton GF, Potts PM, Gunnarsson TG (2014) Why is timing of bird migration advancing when individuals are not? Proc R Soc B 281: 20132161

> Graham RM, De Boer AM (2013) The dynamical subtropical front. J Geophys Res 118:5676-5685

> Guinet C, Cherel Y, Ridoux V, Jouventin P (1996) Consumption of marine resources by seabirds and seals in Crozet and Kerguelen waters: changes in relation to consumer biomass 1962-85. Antarct Sci 8:23-30

> Guinet C, Chastel O, Koudil M, Durbec JP, Jouventin P (1998) Effects of warm sea-surface temperature anomalies on the blue petrel at the Kerguelen Islands. Proc R Soc B 265:1001-1006

> Hall A, Visbeck M (2002) Synchronous variability in the Southern Hemisphere atmosphere, sea ice, and ocean resulting from the Annular Mode. J Clim 15:3043-3057

Hays GC, Richardson AJ, Robinson C (2005) Climate change and marine plankton. Trends Ecol Evol 20:337-344

> Heath RA (1981) Oceanic fronts around southern New Zealand. Deep-Sea Res A, Oceanogr Res Pap 28:547-560

> Hickling R, Roy DB, Hill JK, Fox R, Thomas CD (2006) The distributions of a wide range of taxonomic groups are expanding polewards. Glob Change Biol 12:450-455

> Hilton GM, Thompson DR, Sagar PM, Cuthbert RJ, Cherel Y, Bury SJ (2006) A stable isotopic investigation into the causes of decline in a sub-Antarctic predator, the rockhopper penguin Eudyptes chrysocome. Glob Change Biol 12:611-625

> Hobson KA, Welch HE (1992) Determination of trophic relationships within a high Arctic marine food web using $\delta^{13} \mathrm{C}$ and $\delta^{15} \mathrm{~N}$ analysis. Mar Ecol Prog Ser 84:9-18

> Hyrenbach KD, Forney KA, Dayton PK (2000) Marine protected areas and ocean basin management. Aquat Con- serv 10:437-458

Jaeger A, Cherel Y (2011) Isotopic investigation of contemporary and historic changes in penguin trophic niches and carrying capacity of the Southern Indian Ocean. PLOS ONE 6:e16484

Jaeger A, Lecomte VJ, Weimerskirch H, Richard P, Cherel Y (2010) Seabird satellite tracking validates the use of latitudinal isoscapes to depict predators' foraging areas in the Southern Ocean. Rapid Commun Mass Spectrom 24: 3456-3460

Keeling CD (1979) The Suess effect: ${ }^{13}$ Carbon and ${ }^{14}$ Carbon interrelations. Environ Int 2:229-300

> Klages NTW, Cooper J (1992) Bill morphology and diet of a filter-feeding seabird: the broad-billed prion Pachyptila vittata at South Atlantic Gough Island. J Zool 227: 385-396

> Laws EA, Popp BN, Bidigare RR, Kennicutt MC, Macko SA (1995) Dependence of phytoplankton carbon isotopic composition on growth rate and $\left[\mathrm{CO}_{2}\right]_{\mathrm{aq}}$ : theoretical considerations and experimental results. Geochim Cosmochim Acta 59:1131-1138

> Loeb V, Siegel V, Holm-Hansen O, Hewitt R (1997) Effects of sea-ice extent and krill or salp dominance on the Antarctic food web. Nature 387:897-900

Marchant S, Higgins PJ (1990) Pachyptila vittata broadbilled prion. In: Marchant S, Higgins PJ (eds) Handbook of Australian, New Zealand and Antarctic birds, Vol 1: ratites to ducks. Part A: ratites to petrels. Oxford University Press, Melbourne, p 516-521

Nakagawa S, Schielzeth H (2010) Repeatability for Gaussian and non-Gaussian data: a practical guide for biologists. Biol Rev Camb Philos Soc 85:935-956

Nakagawa S, Schielzeth H (2013) A general and simple method for obtaining $\mathrm{R}^{2}$ from generalized linear mixedeffects models. Methods Ecol Evol 4:133-142

- Navarro J, Votier SC, Aguzzi J, Chiesa JJ, Forero MG, Phillips RA (2013) Ecological segregation in space, time and trophic niche of sympatric planktivorous petrels. PLOS ONE 8:e62897

Orsi AH, Whitworth T, Nowlin WD (1995) On the meridional extent and fronts of the Antarctic Circumpolar Current. Deep-Sea Res I 42:641-673

> Parmesan C, Yohe G (2003) A globally coherent fingerprint of climate change impacts across natural systems. Nature 421:37-42

Penney AJ, Parker SJ, Brown JH (2009) Protection measures implemented by New Zealand for vulnerable marine ecosystems in the South Pacific Ocean. Mar Ecol Prog Ser 397:341-354

> Perry AL, Low PJ, Ellis JR, Reynolds JD (2005) Climate change and distribution shifts in marine fishes. Science 308:1912-1915

> Phillips RA, Silk JRD, Croxall JP, Afanasyev V, Briggs DR (2004) Accuracy of geolocation estimates for flying seabirds. Mar Ecol Prog Ser 266:265-272

> Phillips RA, Bearhop S, McGill RAR, Dawson DA (2009) Stable isotopes reveal individual variation in migration strategies and habitat preferences in a suite of seabirds during the nonbreeding period. Oecologia 160:795-806

Pinheiro J, Bates D, DebRoy S, Sarkar D and R Core Team (2014) nlme: linear and nonlinear mixed effects models. $\mathrm{R}$ package version 3.1-122. http://CRAN.R-project.org/ package $=$ nlme

Pitcher T, Clark M, Morato T, Watson R (2010) Seamount fisheries: Do they have a future? Oceanography (Wash 
DC) 23:134-144

Quillfeldt P, Masello JF, McGill RAR, Adams M, Furness RW (2010) Moving polewards in winter: A recent change in the migratory strategy of a pelagic seabird? Front Zool 7: 15

Quillfeldt P, Masello JF, Navarro J, Phillips RA (2013) Yearround distribution suggests spatial segregation of two small petrel species in the South Atlantic. J Biogeogr 40: 430-441

Quillfeldt P, Cherel Y, Delord K, Weimerskirch H (2015) Cool, cold or colder? Spatial segregation of prions and blue petrels is explained by differences in preferred sea surface temperatures. Biol Lett 11:20141090

R Core Team (2015) R: a language and environment for statistical computing. R Foundation for Statistical Computing, Vienna

Sallée JB, Speer KG, Rintoul SR (2010) Zonally asymmetric response of the Southern Ocean mixed-layer depth to the Southern Annular Mode. Nat Geosci 3:273-279

Schell DM (2000) Declining carrying capacity in the Bering Sea: isotopic evidence from whale baleen. Limnol Oceanogr 45:459-462

Shaffer SA, Tremblay Y, Weimerskirch H, Scott D and others (2006) Migratory shearwaters integrate oceanic resources across the Pacific Ocean in an endless summer. Proc Natl Acad Sci USA 103:12799-12802

Smith RO (2013) Interaction of the subtropical front with topography around southern New Zealand. Deep-Sea Res I 76:13-26

Sonnerup RE, Quay PD, McNichol AP, Bullister JL, Westby TA, Anderson HL (1999) Reconstructing the oceanic ${ }^{13} \mathrm{C}$ Suess effect. Global Biogeochem Cycles 13:857-872

Suess HE (1955) Radiocarbon concentration in modern wood. Science 122:415-417

Sutton P (2001) Detailed structure of the subtropical front over Chatham Rise, east of New Zealand. J Geophys Res 106:31045-31056

Tagliabue A, Bopp L (2008) Towards understanding global variability in ocean carbon-13. Global Biogeochem Cycles 22:GB1025

Thompson DR (2007) Air-breathing visitors to seamounts: importance of seamounts to seabirds. In: Pitcher TJ, Morato T, Hart PJB, Clark MR, Haggan N, Santos RS (eds) Seamounts: ecology, fisheries and conservation.

Editorial responsibility: Jacob González-Solís, Barcelona, Spain
Blackwell Publishing, Oxford, p 245-251

Thompson S, Sydeman WJ, Santora J, Morgan K, Crawford W, Burrows MT (2012) Phenology of pelagic seabird abundance relative to marine climate change in the Alaska Gyre. Mar Ecol Prog Ser 454:159-170

Thuiller W (2004) Patterns and uncertainties of species' range shifts under climate change. Glob Change Biol 10: 2020-2027

> Trull TW, Armand L (2001) Insights into Southern Ocean carbon export from the $\delta^{13} \mathrm{C}$ of particles and dissolved inorganic carbon during the SOIREE iron release experiment. Deep-Sea Res II 48:2655-2680

van Franeker JA, van den Brink NW, Bathmann UV, Pollard RT, de Baar HJ, Wolff WJ (2002) Responses of seabirds, in particular prions (Pachyptila sp.), to small-scale processes in the Antarctic Polar Front. Deep-Sea Res II 49: 3931-3950

> Vermeer K, Fulton JD, Sealy SG (1985) Differential use of zooplankton prey by Ancient murrelets and Cassin's auklets in the Queen Charlotte Islands. J Plankton Res 7: 443-459

- Weaver PPE, Carter L, Neil HL (1998) Response of surface water masses and circulation to Late Quaternary climate change east of New Zealand. Paleoceanography 13: 70-83

Weimerskirch H, Inchausti P, Guinet C, Barbraud C (2003) Trends in bird and seal populations as indicators of a system shift in the Southern Ocean. Antarct Sci 15:249-256

Wessel P (2001) Global distribution of seamounts inferred from gridded Geosat/ERS 1 altimetry. J Geophys Res 106:19431-19441

- Wiley AE, Ostrom PH, Welch AJ, Fleischer RC and others (2013) Millennial-scale isotope records from a wideranging predator show evidence of recent human impact to oceanic food webs. Proc Natl Acad Sci USA 110: 8972-8977

Wilson RP, Ducamp JJ, Rees G, Culik BM, Niekamp K (1992) Estimation of location: global coverage using light intensity. In: Priede IM, Swift SM (eds) Wildlife telemetry: remote monitoring and tracking of animals. Ellis Horward, Chichester, p 131-134

Worm B, Lotze HK, Myers RA (2003) Predator diversity hotspots in the blue ocean. Proc Natl Acad Sci USA 100: 9884-9888

Submitted: May 27, 2015; Accepted: August 16, 2016 Proofs received from author(s): October 5, 2016 